\title{
Aspects Regarding Maize Crops in the Southeast Region of Romania
}

\author{
Cristina STOICA DINCA ${ }^{\star}$, Iuliana Manuela DUMITRU ION ${ }^{\star \star}$, \\ Dumitrache Bogdan BRATOVEANU ${ }^{\star \star \star}$, Silvius STANCIU ${ }^{\star \star \star \star}$
}

\begin{tabular}{l}
\hline \multicolumn{1}{c}{ A R T I C L E I N F O } \\
\hline Article history: \\
Accepted August 2020 \\
Available online August 2020 \\
\hline JEL Classification \\
Q14, Q18 \\
Keywords: \\
Corn, Culture, Cereal grains
\end{tabular}

\section{Introduction}

Agriculture is the main branch of the economy, in all countries of the world being focused in recent years on food security increase, which involves the supply with sufficient, safe and nutritious food, which meet the food needs and preferences of the population for an active and healthy life (Stanciu, 2017a). Cereal cultivation is, globally, a basic source of food for humans and animals raised by humans, being spread over an area of 680-700 million ha, which represents $50 \%$ of the arable land of our planet. (Iosif (Tatomir), 2011).

The maize crops have a special importance, the corn grains being used in human nutrition, as animal feed and also as raw material in industry. According to data from FAO (2018), quoted by Romanian Association of Maize Producers (APPR), about $21 \%$ of world corn production is used in human nutrition, $72 \%$ in animal feed and $7 \%$ in food industry as raw material (APPR, 2020). The particular importance of corn cultivation stems from the fact that it has a number of peculiarities such as high productivity per hectare, safer crops, it is resistant to drought and affected by fewer diseases and pests, adapts with good results in various climatic and soil conditions, leaves the land clean of weeds, good precursor vegetable crop for most crops, can be used as a second crop after early harvest plants, requires a small amount of seed for sowing producing about $50 \%$ higher compared to other cereals, the harvest can be used in various ways (Bîlteanu \& Bîrnaure, 1991). Cereal grains represent the staple food for almost the entire population of the globe, as these are used in various forms, ground and prepared in the form of bread, semolina, pasta, polenta, etc. or cooked and consumed as such. In the form of whole or ground grains, as green, dried or ensiled plants, as secondary products (straw, chaff or maize stalks) and by-products (bran) these are used in the feeding of all species of animals raised by humans. Cereal grains are used as a raw material for a number of industries, such as medical alcohol, alcohol, starch, beer, dextrin, glucose, etc. (Ion, 2010). The maize production corn is influenced by the quality of seeds used for sowing which should have increased value of germination and purity (Stoica et al., 2017).

\section{Materials and methods}

The methods used for the drawing up of the paper were analysis, synthesis and comparison. Data on agricultural areas cultivated with corn and production obtained, as well as data on the fleet of agricultural equipment and the situation of irrigated areas were selected from AgroPortal, Food and Agriculture Organization of the United Nations FAO, National Institute of Statistics INS, Statistical Yearbook of Romania, Eurostat database, the database of the Directorate-General for Parliamentary Research Services of the Parliament. Data provided by the European Commission EC, Organization for Economic Cooperation and

$\star \star \star \star \star \star \star \star \star \star \star \star$ Dunarea de Jos University of Galati, Romania. E-mail addresses: dincacristina2007@yahoo.com (C. Stoica Dinca), iulianaion12@yahoo.com (I.M. Dumitriu Ion), bbratoveanu@ugal.ro (D. B. Bratoveanu), sstanciu@ugal.ro (S. Stanciu - Corresponding author) 
Development OECD, FAO were used for international standards. Where necessary, data from the research literature or from the profile journals in Romania were selected and used, with appropriate citation. The information collected was analysed, statistically processed and graphically represented. The interpretation of the results was correlated, where necessary, with other materials from the research literature.

\section{Results and discussions}

The performance in agriculture can be achieved only when the factors that contribute to the obtainment of the harvest interact and get close to the optimal values necessary for plants. This global condition is rare in natural areas, but any of the factors mentioned can be shaped and directed by man (Vătămanu, 2016) The corn harvest obtained is the result of the interaction of all climatic, technological and pedological factors, the level of harvests being directly related to the degree to which each factor and all together approach the optimal values required by crop biology (Stanciu S., 2016) In national agriculture, corn is the most widespread crop after wheat, as on $76 \%$ of the agricultural territory of the country the thermal factor is favourable and very favourable to corn cultivation and it can ensure high yields. The heat and implicitly the light factor can be modified to a lesser extent, but their degree of capitalization can be much improved by the measures we can apply, such as: zoning the corn crop, its distribution on the territory taking into account the heat necessary to reach maturity and ensure high yields, the creation and use of hybrids with a larger leaf area, with rapid vegetative growth, the choice of an appropriate density of plants per unit area and the orientation of the rows so that all plants receive the maximum possible heat and light, and the assimilated organic mass production to be maximum per unit area (Stanciu et al, 2015). According to Eurostat (2020), Romania ranks first in Europe in terms of the agricultural areas cultivated with corn for consumption, being followed by France, Hungary, Italy, Germany and Spain (Figure 1)

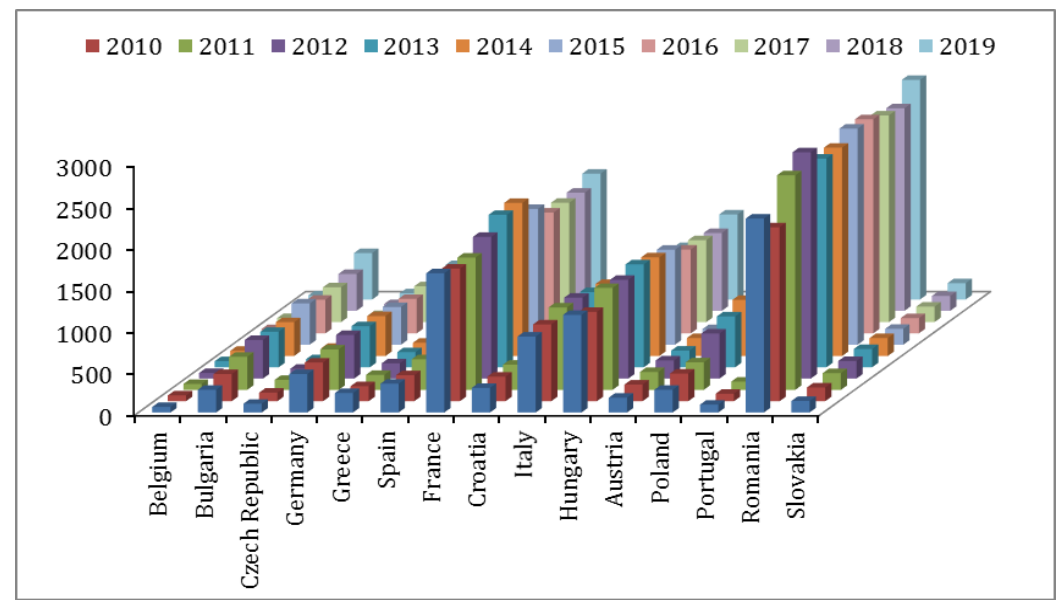

Figure 1. Agricultural areas for maize production in Europe Source: Authors, based on Eurostat (2020)

According to Eurostat (2019), in Romania, an area between 2098.47 thousand ha (2010) and 2731.16 thousand ha (2012) is allocated each year to corn crops. With an average total corn production of 8,945 thousand tons. Romania ranks second in Europe after France (14,878 thousand tons), the next positions being occupied by Italy $(8,421$ thousand tons), Hungary $(7,093$ thousand tons) and Germany $(4,587$ thousand tons). In 2018, with a total production of over 17 million tons, Romania succeeded for the first time exceed France the production of maize (Figure 2).

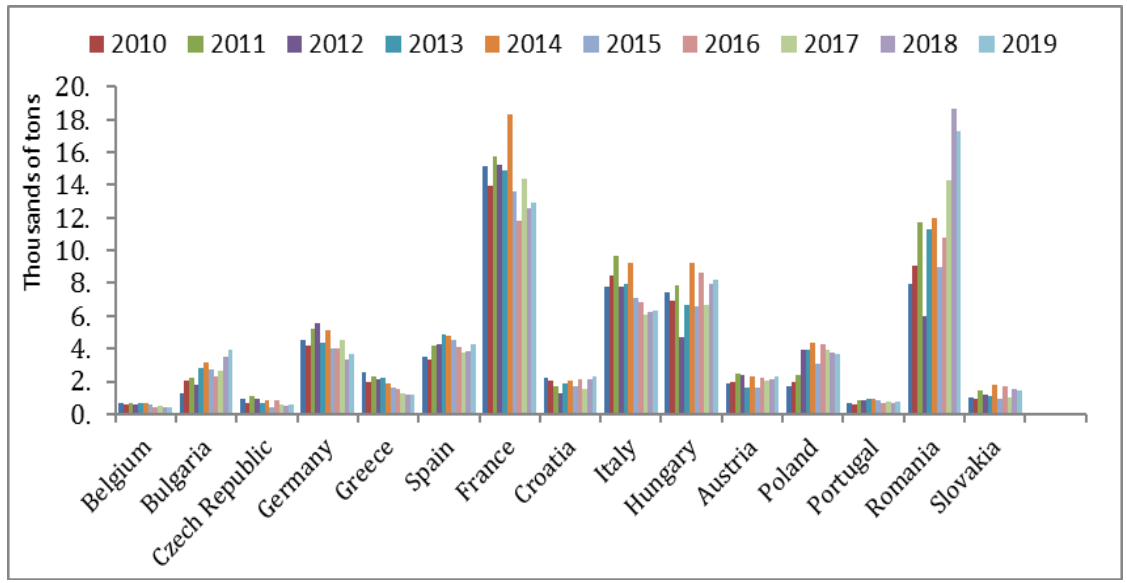

Figure 2. Maize production for consumption in Europe

Source: Authors, based on Eurostat (2020) 
At European level, there is a positive evolution of corn production, more pronounced in the case of France and Romania and slightly lower for Italy and Hungary. Romania's climate is favourable for corn cultivation, having six areas of favourability, depending on the thermal potential, respectively the sum of biologically active temperatures ( $\sum \mathrm{TBA}$ ), with the biological threshold of $10^{\circ} \mathrm{C}$ (Ion, 2010) (Table no.1).

Table 1. The distribution of maize crops according to the temperature regime in Romania

\begin{tabular}{|c|c|c|c|}
\hline Type of hybrid & FAO & $\left(\sum \mathrm{TBA}\right)\left({ }^{\circ} \mathrm{C}\right)$ & Zone \\
\hline Very extra-early & $100-200$ & $800-1000$ & NW of Moldova (Suceava County) and all sub-mountain regions. \\
\hline Extra-early & $100-300$ & $1000-2000$ & $\begin{array}{l}\text { NE of Moldova, Colinele Moldovei West to Siret, Transilvania Plain and Plateau, } \\
\text { the Hills of SE Banat }\end{array}$ \\
\hline Early corn & $200-400$ & $1201-1400$ & $\begin{array}{l}\text { most of Moldova between Siret and Prut, the East of Crişana Plain, the Someş } \\
\text { Plain, the Northern hills of Oltenia and Muntenia, the hilly areas in the West of the } \\
\text { country, }\end{array}$ \\
\hline Semi-early & $350-500$ & $1401-1500$ & $\begin{array}{l}\text { the rest of the Banat Plain, the western half of the Crişana Plain, the Southern hills } \\
\text { of Oltenia and Muntenia. }\end{array}$ \\
\hline Semi-late & $400-600$ & $1501-1600$ & $\begin{array}{l}\text { The Plains of Oltenia and Muntenia, the Plain of southern Moldova, the East of } \\
\text { Dobrogea and the West of the Banat Plain, }\end{array}$ \\
\hline Late & $460-600$ & $>1600$ & Oltenia, Muntenia and Dobrogea plains \\
\hline
\end{tabular}

In Romania, in the period 2010-2019, corn productions registered significant annual increases, but were permanently influenced by the precipitation regime during the vegetation period. Although the average yields per hectare are still low compared to those obtained by other EU countries, the largest quantity of corn in Europe of 18,812 thousand tons was obtained in 2018. (Eurostat, 2019) (Figure 3).

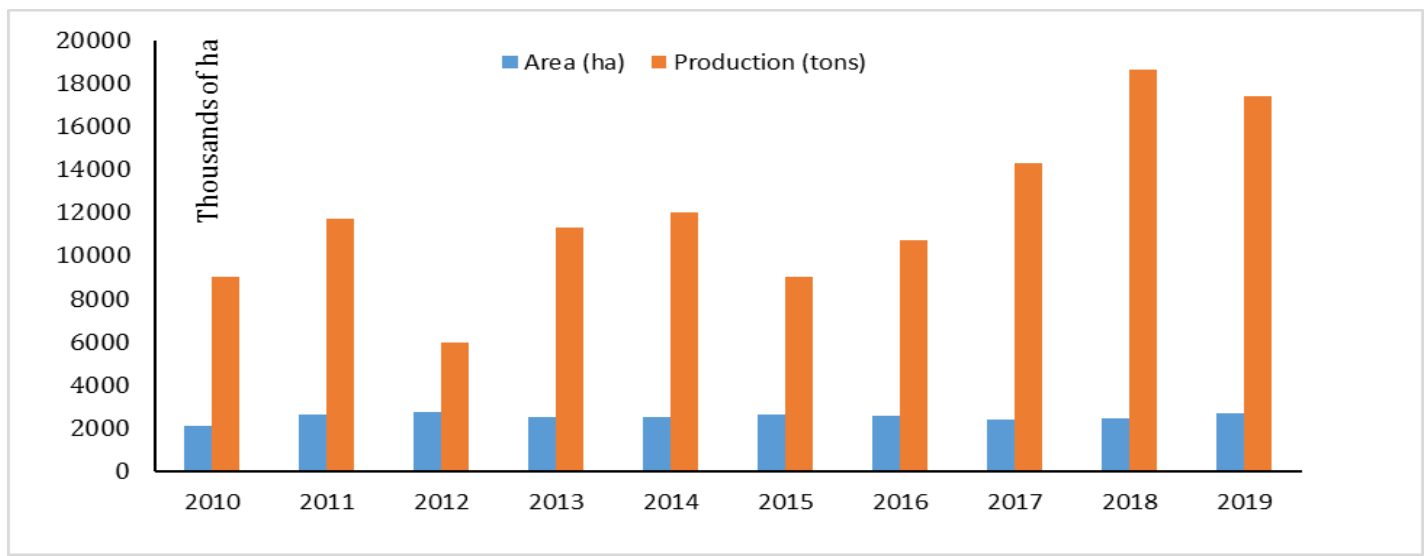

Figure 3. Area and maize production in Romania (2010-2019)

Source: Authors, based on National Institute of Statistics NIS (2020)

The increase in the quantities of corn harvested per hectare is due to the increase of the number of technical equipment of agricultural farms, the application of high-performance agricultural technologies and the use of hybrid corn seeds, with different maturity groups, adapted to each crop area and last but not least to climatic conditions (Figure 4).

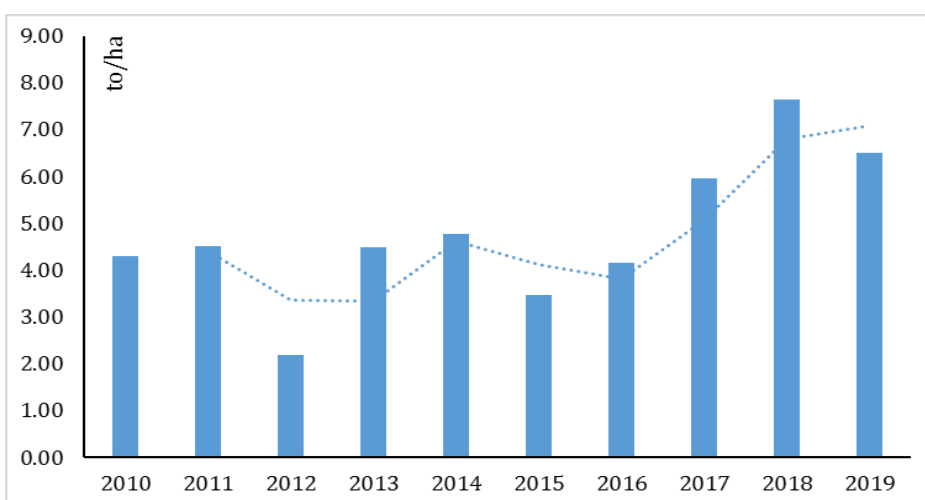

Figure. 4 Crops area and maize production in Romania-(2010-2019)

Source: Authors, based on National Institute of Statistics NIS (2020)

When choosing a hybrid, the following elements must be taken into account: the precocity group (vegetation period), the hybrid must reach maturity before the arrival of autumn frosts, and for safety it must have the necessary biologically active temperatures (TBA) smaller by at least $100^{\circ} \mathrm{C}$ compared to the potential of the area, the production capacity, which must be high and as constant as possible from one year 
to another, to be resistant to drought and heat, to be resistant to diseases and pests, to be resistant when falling and breaking, to have a uniform insertion of the cobs and a good suitability for mechanized harvesting (Ion, 2010). In order to capitalize as efficiently as possible on the potential of the area in terms of corn cultivation, special attention must be paid to the choice of corn hybrids according to precocity and the requirements of each one in relation to the climate and soil conditions. For a better statistical collection and information analysis, after 1998 the Romanian territory was divided into 4 development macro-regions, according to the classification of the Nomenclature of Territorial Units for Statistics NUTS I, used by EU member states. The share of agricultural area cultivated with corn in Romania in 2018 on the macro-regions is presented in figure no. 5 .

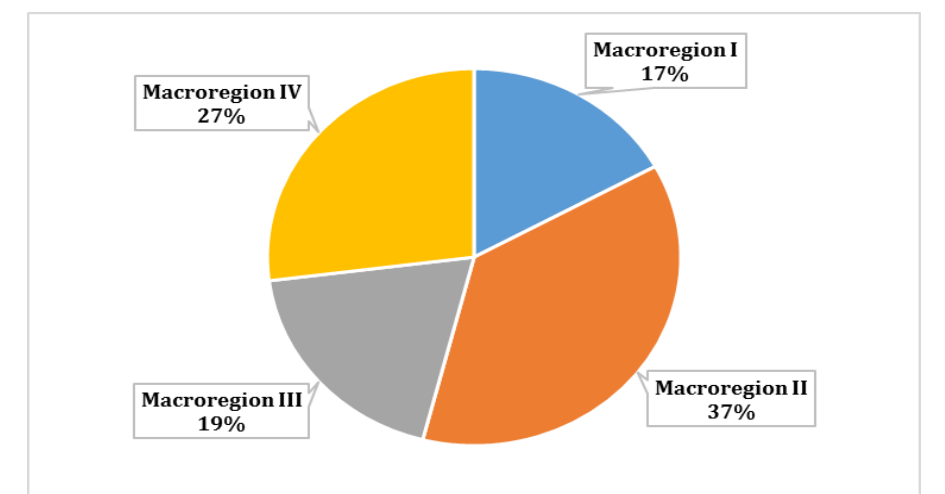

Figure 5. Areas allocated to maize in Romania by macro regions Source: Authors, based on NIS (2020)

Macro region II with an area of 954,999 thousand ha representing 37\% of the total cultivated area with corn is highlighted in red, followed by Macroregion IV with an area of 705,717 thousand ha, representing $27 \%$ of the total and then Macroregion III and IV with 482,003 thousand ha respectively 438,265 thousand ha representing $19 \%$ and $17 \%$ respectively of the total. The situation of the areas cultivated in 2018 with corn in the counties from Macroregion II are presented in figure 6.

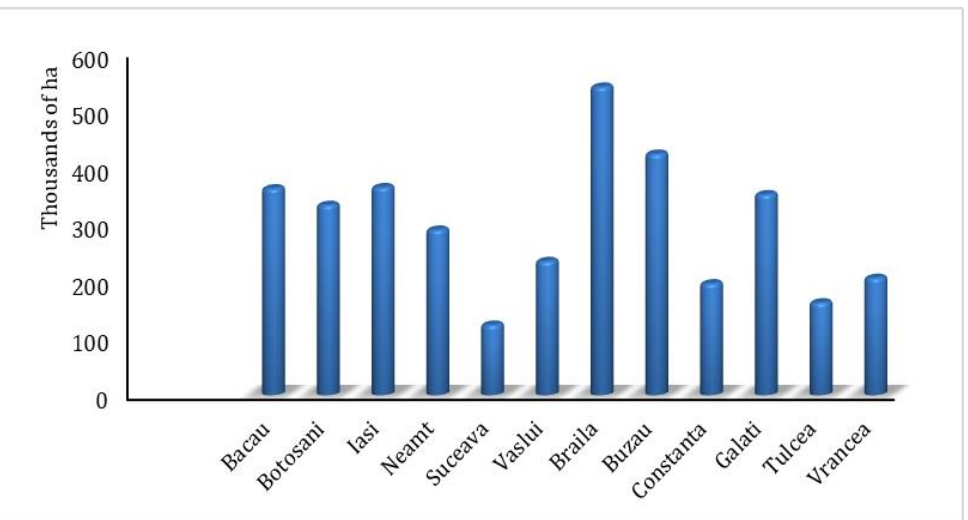

Figure 6. Areas cultivated with maize in Macroregion II, by counties Source: Authors, based on NIS (2020)

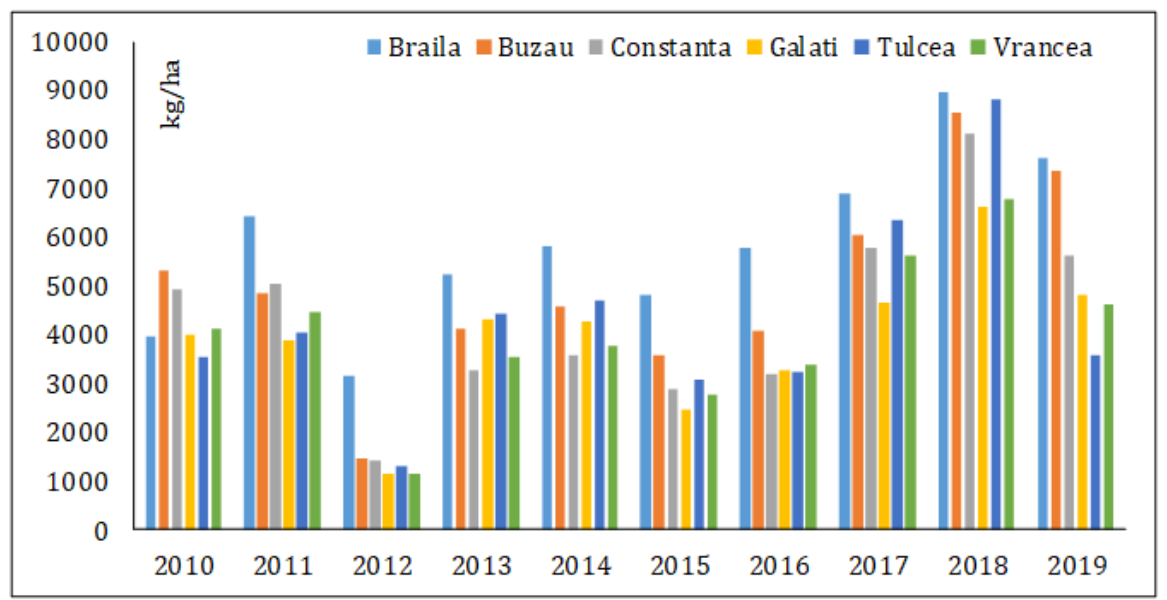

Figure 7. Average productions of maize in Macroregion II, by counties (2010-2020) Source: Authors, based on NIS (2020) 
An analysis of the areas cultivated with corn in Romania shows an uneven distribution of it on the 4 macro regions, influenced by soil and climatic factors, the application of irrigation systems or by the endowment of farms with equipment. The average yields per hectare obtained are in turn influenced by the applied cultivation technologies, by the seed used to sow the crops as well as by the irrigated areas. (Figure 7)

In the last 10 years, significant investments have been made in the renewal of the agricultural machinery fleet in Romania, numerous factors contributing to the achievement of these modernization investments (Stanciu et al, 2015). European funds made available to farmers, the Rabla program, special cofinancing credits, the appearance of second-hand machinery on the market were some of the factors that supported farmers in purchasing machinery. (Stanciu, 2017b) One of the most important reasons behind these investments is the fact that the number of modern, high-performance farms with large areas has increased significantly in recent years (NIS, 2022) (Figure 8).

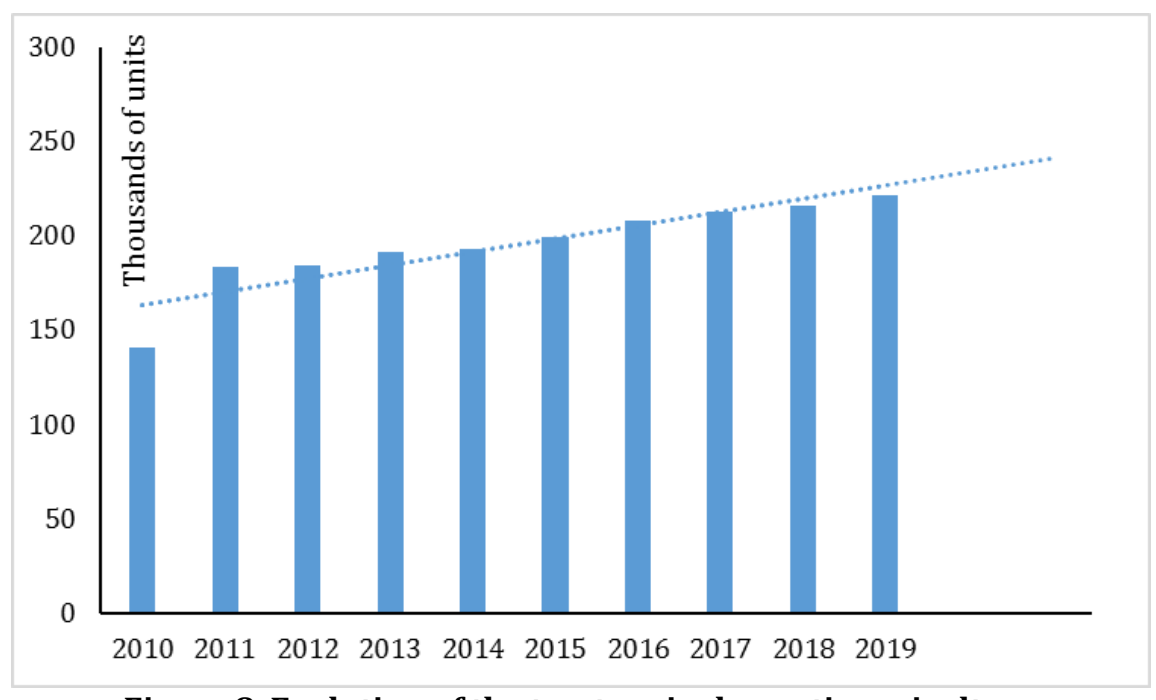

Figure 8. Evolution of the tractors in domestic agriculture Source: Authors, based on NIS (2020)

By analyzing the data from figure 6, after 2010 it can see an increase in the degree of endowment of domestic farms with high-performance tractors in particular, which, against the background of favourable climatic conditions, allowed the obtainment of more and more crops. At the level of macroregion II one can see a sustained annual growth of the agricultural tractor fleet (Figure 9).

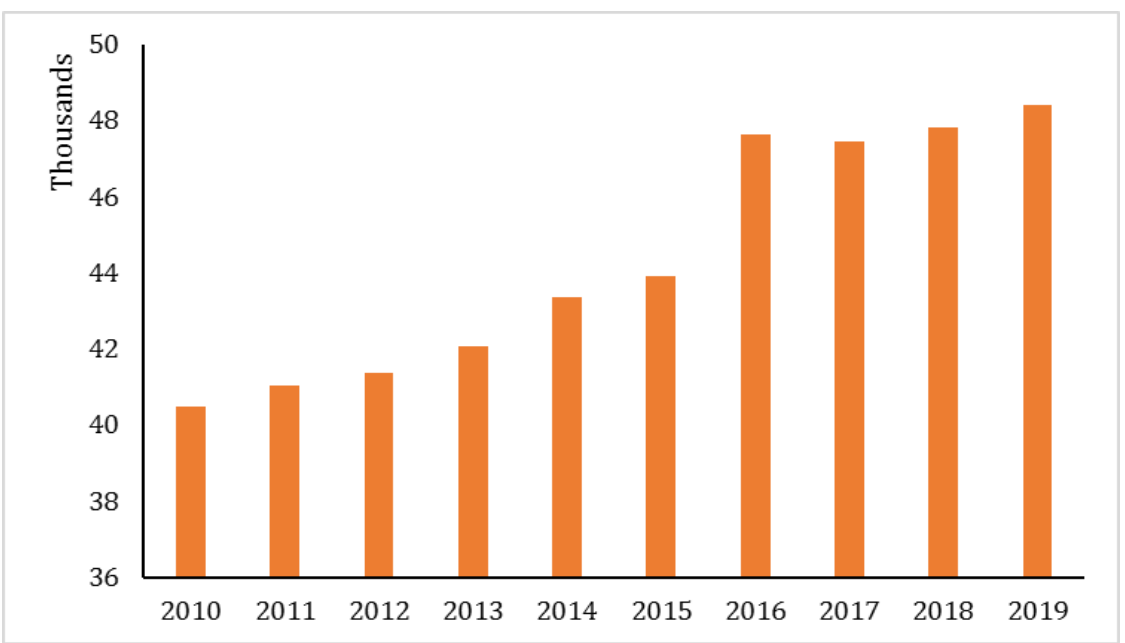

Figure 9. Evolution of endowments with agricultural tractors in the macroregion II Source: Authors, by using NIS (2019)

Another important factor that influences the cultivation of corn is the use of irrigation in agriculture. The most important agricultural areas arranged for irrigation are in Macroregion II (197,000 216,000 ha) (Figure 8). 


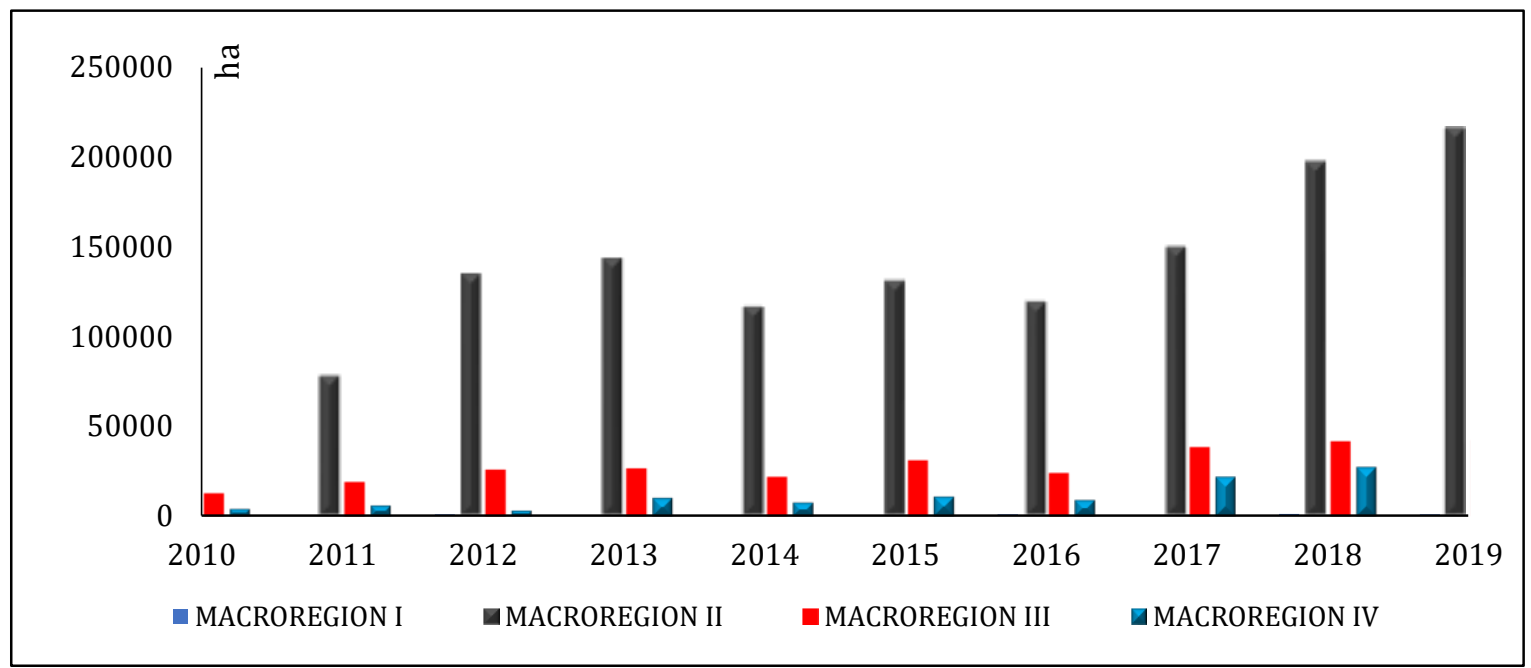

Figure 10. Agricultural area irrigated, by macro regions

Source: Authors, by using NIS (2020)

Part of the water needs of agricultural crops can be estimated based on climatic conditions, and the other part needs to be ensured by irrigation. Macroregion II occupies the first position in Romania as irrigated agricultural areas, the last position being occupied by Macroregion I.

\section{Conclusions}

Knowing the relationships between vegetation and plant factors gives the grower the opportunity to control, regulate and direct the action thereof within certain limits, to ensure optimal conditions for the normal development of the biological cycle and to obtain the expected yields by using the technical means available. The achievement of high and quality productions that satisfy both the market and the farmers must be the result of the cumulation of several factors that are favourable to the corn crop. First of all, in Brăila County, corn meets the best conditions for development, the climatic, technical and social factors being favourable to this crop. The maintenance and development of the irrigation infrastructure, the existence of compact land areas where works with high-performance equipment can be performed, is another advantage of the area. In order to effectively exploit the potential of the area in terms of corn cultivation, more attention must be paid to the choice of corn hybrids according to the maturity group and the requirements of each one in terms of the climatic and soil conditions. Based on the data presented above, it can be seen that the technical endowments and the presence of areas equipped with irrigation systems lead to the concentration of zones cultivated with consumption corn in areas that provide the best growing conditions, respectively in Macro region 2. In recent years' significant annual increase in corn production can be observed, but were permanently influenced by the rainfall regime during the vegetation period. Although the average yields per hectare are still low compared to those obtained by other EU countries, in 2018 the largest quantity of corn in Europe of 18,812 thousand tons was obtained. Following the analyses performed, it can be seen that the Romanian corn production is influenced by climatic factors, the endowment with state-of-the-art equipment, the presence of irrigation systems, modern agricultural technologies. The results obtained highlighted the existence of significant differences between regions in terms of consumption corn culture, by means of the organization of small farms in cooperatives that could become competitive in the agricultural market.

\section{Acknowledgment}

„This work is supported by the project ANTREPRENORDOC, in the framework of Human Resources Development Operational Programme 2014-2020, financed from the European Social Fund under the contract number 36355/23.05.2019 HRD OP /380/6/13 - SMIS Code: 123847."

\section{References}

1. APPR Asociatia Producatorilor de Porumb din Romania, (2020), Porumbul, floarea-soarelui si sfecla, principalele culturi din Romania afectate de Strategia pentru Biodiversitate, Gazeta de Agricultura (23.06.2020), [online], available at https://www.gazetadeagricultura.info/plante/cereale/433-porumb/22435-porumbul-floarea-soarelui-si-sfecla-principalele-culturidin-romania-afectate-de-strategia-pentru-biodiversitate.html. [accessed 03.08.2020].

2. Bîlteanu, V. Bîrnaure, (1991), Fitotehnie, Editura Didactica si Pedagogica, Bucuresti.

3. Eurostat, (2020), Green maize by area, production and humidity, online, available at https://ec.europa.eu/eurostat/web/productsdatasets/-/tag00101.

4. Food and Agriculture Organization of the United Nations FAO, (2018), AGP-Seed Rules and Regulatory Frameworks, [online], [Retrieved February 12, 2020), 
5. Ion, V., (2010), Manual de Fitotehnie, [online], available at http://www.horticultura-bucuresti.ro/images/pdf/Fitotehnie, 2010 pdf, [accessed 25.06.2020].

6. Iosif (Tatomir) E., (2011), Cercetări asupra culturii grâului și porumbului - situaţia actuală şi perspective, în contextul evoluțiilor la nivel european şi mondial, Teza de doctorat, USAMV Bucuresti, Rezumat, [online], available at

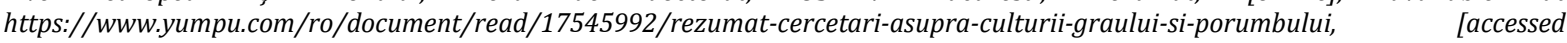
22.07.2020].

7. National Institute of Statistics NIS, [2020], Agriculture, [Tempo online], available at http://statistici.insse.ro:8077/tempoonline/\#/pages/tables/insse-table, [accessed 23.06.2020].

8. Stanciu, S., (2016), Crop Management. Case Study: Romanian Soybean Production, Review of International Comparative Management, 17(4), 392-402.

9. Stanciu, S., (2017a), Yields and Land Use for Wheat Production in Romanian Agriculture, Proceedings of 30th IBIMA Conference (Madrid, Spain, Nov. 08-09, 2017), ISBN:978-0-9860419-9-0, Ed. Soliman, K.S., Vols. I-IV, 3033-3040.

10. Stanciu, S., (2017b), An Analysis of the Romanian Storage Capacity for Seed Production, Proceedings of The 29th IBIMA Conference (Viena, Austria, May 3-4, 2017), ISBN 978-0-9860419-7-6, Ed. Soliman, K.S., Vols. I-IV, 1200-1207.

11. Stanciu, S., Rizea, R. D., Ilie A. G., (2015), Study on the Competitiveness of the Romanian Meat Processing Industry. Amfiteatru Economic, 17 (Special No. 9),1331-1345.

12. Stoica (Dinca), C., Băcanu (Serban) C., Stanciu S., (2017), Romanian certified seed production, Proceedings of the 30th IBIMA Conference, (Madrid, Spain, Nov. 08-09, 2017, ISBN:978-0-9860419-9-0, Ed. Soliman, KS., Vols. I-IV, 3198-3207.

13. Vătămanu, V., (2013), Cerintele fata de temperatura ale culturii de porumb boabe, Agrimedia (15.07.2013), [online], available at https://www.agrimedia.ro/articole/cerintele-fata-de-temperatura-ale-culturii-de-porumb-boabe, [accessed 21.07.2020]. 